ISBN : 978-602-422-196-6

The $1^{\text {st }}$ Qualitative Research for Civilization Conference (QRCC)
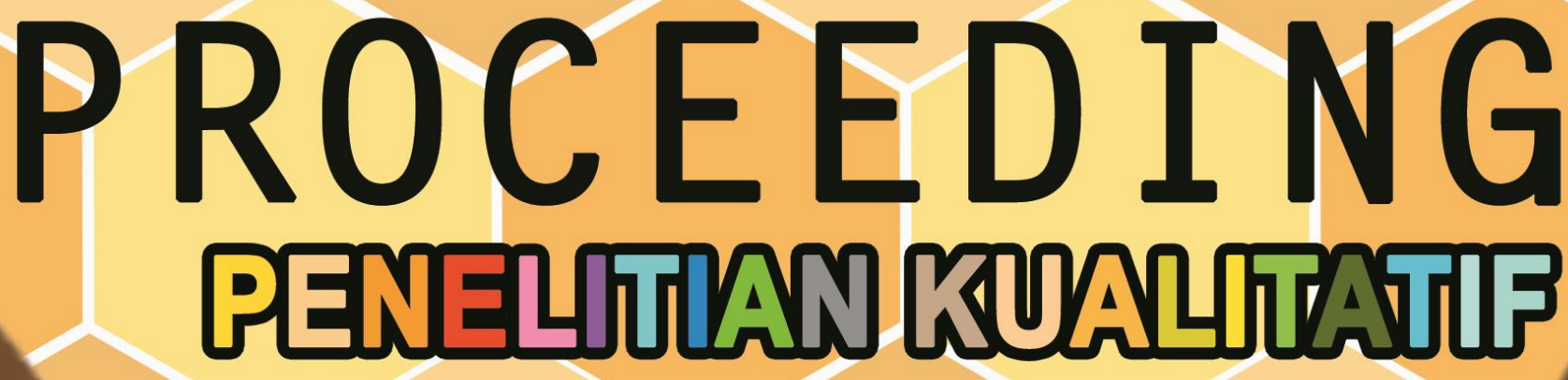

SEM I NAR

NAS I ONAL

PENELITIAN KUALITATIF MEMBANGUN KEINDONESIAAN 




\section{Daftar Isi}

Efektivitas Pelaksanaan Program Nasional Pemberdayaan Masyarakat

Halaman

Pembangunan Infrastruktur Sosial Ekonomi Wilayah di Kabupaten

Tabalongkalimantan Selatan

1 - 25

\section{Erwan}

Social Space of Modern and Traditional Market: A Phenomenological Study in

Kendary City

\section{Peribadi}

Kewirausahaan dan Kebijakan Negara (Studi Kebijakan Pemerintah Terhadap Pelaku UKM di Provinsi Kalimantan Selatan)

\section{Sayuti Enggok}

Pemberdayaan Petani Sebagai Upaya Meningkatkan Ketahanan Pangan (Studi Tentang Program Gabungan Kelompok Tani di Desa Menganti, Kecamatan Menganti, Gresik)

\section{Ertien Rining Nawangsari}

Implementasi Prinsip-Prinsip Akuntansi Islam pada Pembiayaan Mudharabah di Bank Muamalat Indonesia

\section{Siti Nurhasanah}

Fenomenologi Komunikasi Anak Jalanan Telaah Gaya Penyesuaian Diri Dalam Lingkungan Orang Dewasa Pada Anak Jalanan di Kota Cirebon

\section{Atwar Bajari}

Membedah Strategi Program Tayangan India Dalam Industri Televisi Indonesia 2014-2017 Melalui Studi Kasus

\section{Melisa Indriana Putri}

Pembentukan Citra PT Kereta Api Indonesia (Persero) Melalui Revitalisasi Stasiun Kereta Api (Studi Kasus Revitalisasi Stasiun Besar Yogyakarta)

\section{Doddy Wihardi}

Implementasi Kebijakan Standar Program Siaran di Lembaga Penyiaran Publik Televisi Republik Indonesia Sumatera Selatan

\section{Nurmah Semil, Muzhar Apandi}

Identitas Kebudayaan Dalampesan Iklan di Media Online (Studi Deskriptif Kualitatif Iklan Kit Kat Versi Pendekar Golok Emas dan Kamentok Rider di Youtube)

\section{Oktaviana Purnamasari}

Kajian Netnografi Penggunaan Media Sosial Facebook untuk Komunikasi Menyusui

\section{Wichitra Yasya}

Peran Media Sosial Twitter Dalam Membentuk Gerakan Sosial 249-270 \#MelawanAsapdiRiau 


\section{Intan Mulyana, Nani Nurani Muksin}

Kerja Sama Jepang dan Filipina Dalam Bidang Tenaga Kerja Sebagai Indikator Pembangunan

\section{Denada Faraswacyen L. Gaol}

Persepsi Akademisi Mengenai Penganguran Terbuka 2016 di Jawa Barat Serta Kebijakan Dalam Rangka Menanggulanginya

\section{Hamirul, Dedi Epriadi}

Kajian Penologi Terhadap Pola Penghukuman yang Dilakukan Oleh Bidang Propam Polda Metro Jaya Dalam Menangani Penyimpangan Polisi

\section{Nuri Andrian}

Evaluasi Pelaksanaan Tugas Unit Pelaksana Teknis Dinas Pendidikan Kecamatan Rantau Pandan Kabupaten Bungo Provinsi Jambi

\section{Dedi Epriadi, Hamirul}

Pelayanan Sepenuh Hati Dengan Penerapan Standar Pelayanan Publik di 338-355 Rusunawa Rawabebek DKI Jakarta

\section{Retnowati Wd Tuti, Mawar}

Politik Perkotaan di Surabaya Pada Kepemimpinan Tri Rismaharini Tahun 20102015: Studi Kasus Revitalisasi Kampung Dolly

\section{Lusi Andriyani}

Pendekatan Komunikasi Antar Budaya Membangun Keindonesiaan Melalui Berbagai Media

\section{Armawati Arbi}

Fenomena Perilaku Seks Bebas Remaja Putri di Purwokerto

\section{S. Bekti Istiyanto, Maharrani Dwi K}

Komunitas Virtual Keagamaan: Pendisiplinan Beragama di Era Digital

Mite Setiansah, Nana Sutikna

Identitas Budaya Etnik Cina \& Etnik Melayu di Bangka

Agustina Zubair

Komunikasi Migran Sunda Dengan Masyarakat Desa Babussalam Kecamatan Marbau-Labuhanbatu Utara

\section{Lusiana Andriani Lubis}

Praktik Tolong Menolong Dalam Program Persaudaraan Madani di Kota Kendari: dari Karitas Menuju Pemberdayaan

\section{Darmin Tuwu}

Modal Sosial Dalam Budaya Tarian Lego-Lego Masyarakat Alor Nusa Tenggar Timur

\section{Welhelmina Selfina Beli}

Model Penguatan Modal Sosial (Studi Kasus Pada Komunitas Nelayan di Pulau Makasar Kota Bau-Bau)

\section{Tanzil}

Makna Peran Diri Dalam Keluarga Pada Suami Buruh Migran: Studi Kasus di Kecamatan Sliyeg, Indramayu 
Slamet Mulyana, Meria Octavianti

Sistem Komunikasi Pemerintah Dalam Kompleksitas Poktan Fiktif 586-601 Pengembangan Kambing Kaligesing di Purworejo

Tatag Handaka

Gatekeeper dan Partisipasi Publik (Studi Kasus Kualitatif Tentang Praktik 602-616 Gatekeeper di Radio Suara Surabaya)

\section{Ido Prijana Hadi}

Integrasi Pendekatan Top-Down dan Bottom-Up dalam Community Development $617-632$ (Studi Pada Upaya Peningkatan Kualitas Hidup Masyarakat Kampung Down Syndrome di Kabupaten Ponorogo)

Falih Suaedi, Genut Wahyu Widiono

Keberhasilan Program Keluarga Berencana Pada Kelompok Masyarakat Adat Terpencil Baduy di Kabupaten Lebak Banten

Ahmad Sihabudin, Lidya Wati Evelina

Analisis Pelayanan Pos Pembinaan Terpadu Lanjut Usia Kenari di Kelurahan Keranggan Kecamatan Setu Kota Tangerang Selatan

\section{Sugiyanti dan Retnowati Wd Tuti}

Pola Pengembangan Pengentasan Kemiskinan Melalui Program Beras Miskin (Studi Eksploratif Pengembangan Alternatif Intervensi Sosial Berbasis Evaluasi Penerima Beras Miskin di Dua Kabupaten di Jawa Barat)

Atwar Bajari, Rini Anisyahrini, Ninis Agustini Damayani

Reformasi Birokrasi di DKI Jakarta

$689-703$

\section{Kurniasih Mufidayati}

Obyektivitas Dalam Penelitian Kualitatif: Sebuah Isu Dalam Pembuatan Kebijakan Berbasis Bukti

Lina Miftahul Jannah, Muh. Azis Muslim, Marcel Angwyn

Strategi Integrated Marketing Communication (IMC) Sebagai Upaya 720-740 Meningkatkan Brand Awareness Net Tv

\section{Rahmat Edi Irawan, Merry Fridha}

Efektivitas Komisi Pengawasan dan Perlindungan Anak Daerah Dalam Penanganan Kasus Kekerasan Seksual Anak di Kota Tanjungpinang

Diah Siti Utari, Billy Jenawi, Desmayeti Arfa, Murniati

Pranata dan Kelembagaan Sosial Pada Komunitas Petani

$760-779$

Aryuni Salpiana Jabar, Peribadi

Pemaknaan Kasundaan Pada Individu Tionghoa di Kabupaten Garut, Jawa Barat

\section{Santi Susanti, Dian Sinaga, Fitri Perdana}

Representasi Marxisme dalam Film Sejarah (Kajiansemiotika John Fiske Pertentangan Kelas Sosial Pada Film Guru Bangsa Tjokroaminoto)

Catur Nugroho, Aisyah Nurul K

Fasilitasi Budaya Masyarakat Desa Pesisir dan Perbatasan Dalam Pemberdayaan Ekonomi Masyarakat di Provinsi Kepulauan Riau

Endri Sanopaka, Nurbaiti Usman Siam, Joe Fernandez 
Perlindungan Hukum Konsumen Terhadap Keterlambatan Jadwal Penerbangan

$826-873$

Berbasis Bisnis High Perfomance

Endang Sutrisno, Dikha Anugrah

Peran Media Massa Dalam Edukasi Penyadaran Satwa Dilindungi (Studi Kasus Penayangan Kakaktua Dilindungi di Net Tv dan Trans Tv)

\section{Herlina Agustin, Dadang Rahmat Hidayat}

Implementasi Manajemen Kewirausahaan Sekolah Berbasis Kreativitas dan Inovatif di SMK Negeri 1 Jabon, Kabupaten Sidoarjo

Mashudi, Nurul Laili

Komunikasi Keluarga di Rumah Tidak Layak Huni

$906-921$

\section{Hadi Suprapto Arifin, Meria Octavianti}

Radio Komunitas dan Penanggulangan Bencana Berbasis Kearifan Lokal

$922-932$

Dian Wardiana Sjuchro dan Leili Kurnia Gustini

Uji Kompetensi Jurnalis Dalam Membentuk Profesionalisme Jurnalis

$933-941$

Reni Nuraeni

Pengembangan Model Komunikasi Bisnis Mikro Berbasis Pemberdayaan $942-953$

Masyarakat di Indonesia (Studi Kasus Pengembangan Model Komunikasi Bisnis Mikro Berbasis Pemberdayaan Masyarakat di Kabupaten Garut Provinsi Jawa Barat

\section{Ilham Gemiharto, Hadi Suprapto Arifin}

Pengembangan Kelembagaan Kerjasama Antar Daerah di Jawa Tengah (Studi Kasus Regionalisasi Tempat Pemrosesan Akhir Sampah)

\section{Aris Toening Winarni}

Reformasi Sdm Sebagai Upaya Peningkatan Pembangunan Adil Gender di Kabupaten Sidoarjo

\section{Luluk Fauziah, Mashudi}

Pengembangan Teknik Analisa Interaksi Sistem Flanders (Flanders Interaction Analysis Categories) Dalam Kegiatan Ceramah Agama

Nurul Hidayati, Nunung Khoeriyah, Ade Rina Farida 
Kualitas Pelayanan Publik di Kantor Sistem Administrasi Manunggal Satu Atap 1003 - 1019 (Samsat) Kota Gorontalo

\section{Asna Aneta, Maha Atma Kadji, Hais Dama}

Manajemen Krisis Government Relations PT. Pertamina EP Asset 4 Field Cepu

$1020-1034$

Pada Kasus Kurangnya Pemahaman Pemerintah Terhadap Industri Hulu Migas

Diah Safitri Ningrum, Sa'diyah El Adawiyah

Fenomena Trial by The Mob (Pengadilan Massa) Dalam Kasus Basuki Tjahaja Purnama (Ahok) Ditinjau Dari Aspek Hukum

\section{G.Theodorus L.Toruan}

Interrelasi Pemerintahan Desa Dengan Institusi Adat di Maiwa Kabupaten Enrekang

Syamsul Bahri, M. Natsir Tompo, Rasyidah Zainuddin, Harifuddin Halim

Implementasi Kebijakan Program Rintisan Model Desa Berdikari Provinsi Jawa Tengah Tahun 2015 di Kabupaten Blora

\section{Adi Purwanto}

Kesiapan Pemerintah Desa Dalam Menyambut Dana Desa

\section{Elis Teti Rusmiati, Kasidiyono}

Optimalisasi Karakteristik Lembaga Dalam Implementasi Kebijakan Pelayanan Perijinan Perikanan Tangkap (SIPI) di Jawa Tengah

\section{Kismartini}

Memetakan Tipologi Pemilih DKI Dalam Pilkada 2017

$1111-1128$

\section{Lely Arrianie}

Pelayanan Publik Berbasis ICT di Desa Ubung Kaja, Denpasar Bali

\section{Nyoman Diah Utari Dewi}

Analisis Etnografi Komunikasi Dalam Tradisi Makkobar Pada Upacara 1145-1165 Perkawinan Adat Padanglawas Utara

Rahmanita Ginting, Iskandar Zulkarnain, Nenggih Susilowati

Pemetaan dan Pengembangan Kesenian Tradisional di Malang Raya

\section{Sugeng Winarno}

Strategi Komunikasi Produk (Studi Kasus Strategi Komunikasi Produk 1193-1209 Smartphone Merek Sony yang Mengalami Fase Decline)

\section{Afifatur Rohimah, Ayun Maduwinarti}

Demokratisasi di Indonesia : Pergeseran Peran Tokoh Masyarakat Dalam 1210-1250 Kelompok Sosial Pedesaan (Desa Jambangan ) di Kabupaten Ngawi

Arif Darmawan, Rachmawati Novaria, Tri Yuliati

Memandang Konflik Pertamina VI Balongan Melalui Contentious Politics: 1251-1269 Repertoar Warga Balongan Sebagai Sarana Komunikasi Politik

Beta Puspitaning Ayodya, Dewi Sri Andika Rusmana 


\section{Fitri Norhabiba}

Implementasi Human Relation Pimpinan Pasca Pergantian Kepemimpinan di

$1282-1294$ Organisasi (Human Relations Kepala Sekolah Pasca Pergantian Kepala Sekolah di SMP Negeri 48 Surabaya)

\section{Mohammad Insan Romadhan}

Penataan Kelembagaan Organisasi Perangkat Daerah Kabupaten Sampang

$1295-1314$

Yusuf Hariyoko, Anggraeny Puspaningtyas

Pemasaran Produk Olahan Ikan Laut UKM Kenjeran Surabaya Berbasis Marketing Mix Syariah

\section{Siti Maro'ah}

Analisis Formulasi Perencanaan Pembangunan Jangka Menengah Daerah (RPJMD) Kabupaten Sidoarjo Tahun 2016-2021

\section{Muhammad Zuhdi}

Strategi Pembelajaran PAI Pada Peserta Didik Tuna Grahita SD Kelas Awal di $1358-1378$ SDLB Pembina Tingkat I Cilandak Lebak Bulus Jakarta Selatan

\section{Rika Sa'diyah}

Riset Opini Publik Dalam Industri Politik di Indonesia: Kelembagaan, Publikasi, Peluang, dan Tantangan

\section{Surokim}

Pembelajaran Transformatif - Deliberatif; Upaya Mengembangkan Konsep dan Strategi Pendidikan Islam di Indonesia

\section{Istikomah}

Kedudukan Multi Akad Dalam Pembiayaan Murabahah di Perbankan Syariah

\section{Popon Srisusilawati , Panji Adam}

Kebijakan Peningkatan Mutu Pendidikan (Suatu Studi Tentang Pendidikan Tinggi Pada Akademi Angkatan Laut Surabaya)

\section{Suhirwan}

Implementasi Kebijakan Layanan Terapi dan Rehabilitasi Komprehensif pada Gangguan Penggunaan Napza Berbasis Rumah Sakit di Rumah Sakit Jiwa Daerah Sambang Lihum Provinsi Kalimantan Selatan

\section{Tanwiriah}

Relasi Jiwa dan Perilaku Manusia: Perspektif Filsafat Islam

\section{Humaidi}

Subak Dalam Pusaran Alih Fungsi Lahan di Kecamatan Denpasar Selatan Kota Denpasar

\section{Gede Wirata, Ida Ayu Sri Widnyani}


Compentence Resources of Apparature (Case Study The Development of 1552-1580 Apparature Human Resource Compentence in Kantor Pelayanan Perizinan Terpadu (KP2T) Kabupaten Banjarnegara)

\section{Sumarmo}

Upaya Pemenuhan Hak Politik Penyandang Disabilitas Dalam Pemilihan Umum

$1581-1590$ di Indonesia (Studi Kasus Upaya Pemenuhan Hak Politik Penyandang Disabilitas di Pemilihan Kepala Daerah (Pilkada) 2017 Kota Cimahi Jawa Barat)

\section{Ilham Gemiharto}

Pesan Kampanye Gerakan Cikapundung Bersih di Kota Bandung

Meria Octavianti, Slamet Mulyana

Pancasila Paradoks Telaah Praksis Sosial Politik

$1609-1615$

\section{Suwandi Sumartias, Hamim}

Merajut Ke-Indonesiaan Melalui Penelitian Kualitatif

$1616-1633$

Nina Widyawati

Karakter Corporate Social Responsibility (CSR) Islami dalam Perspektif 1634-1648 Komunikasi PT Pertamina Geothermal Energy Area Kamojang

\section{Neni Yulianita}




\title{
PEMBERDAYAAN PETANI SEBAGAI UPAYA MENINGKATKAN KETAHANAN PANGAN \\ (Studi tentang Program Gabungan Kelompok Tani di Desa \\ Menganti, Kecamatan Menganti, Gresik)
}

\author{
Ertien Rining Nawangsari \\ Administrasi Negara, FISIP,UPN"Veteran" Jatim \\ ertien.riningnawangsari@yahoo.com
}

\begin{abstract}
Abstrak
Pembedayaan petani perlu dilakukan untuk meningkatkan penyediaan bahan pokok di Indonesia. Salah satu upaya adalah dengan Gabungan Kelompok Tani (Gapoktan) adalah program pemberdayaan untuk meningkatkan usaha pertanian dalam pemberdayaan. Upaya meningkatkan produksi petani pada saat ini banyak mengalami hambatan, sehingga perlu adanya peningkatan pemberdayaan masyarakat petani. Tujuan penelitian adalah untuk mendeskripsikan, menganalisis dan menginterprestasikan tentang proses pemberdayaan pertanian sebagai upaya meningkatkan ketahanan pangan melalui program Gapoktan di Desa Menganti Kecamatan Menganti Kabupaten Gresik.

Penelitian ini menggunakan metode deskriptif kualititatif dengan fokus penelitian yaitu Pemberdayaan ekonomi dan pemberdayaan teknologi. Teknik pengumpulan data berupa wawancara, observasi, dan dokumentasi. Analisis data menggunakan model analisis data interaktif.

Hasil penelitian, pemberdayaan ekonomi melalui pendistribusian subsidi pupuk dan bibit tanam yang sudah dilaksanakan memberikan dampak peningkatan kemampuan ekonomi petani dan meningkatkan produksi pertanian. Pemberdayaan teknologi melalui sekolah lapang dan penyuluhan yang dilakukan secara rutin memberikan dampak peningkatan kemampuan teknologi bagi petani dan meningkatkan produksi pertanian. Pemberdayaan petani melalui program Gapoktan sudah berjalan dan memberikan dampak peningkatan keberdayaan petani dalam mengembangkan usaha pertanian sehingga dapat mendukung ketahanan pangan di Indonesia
\end{abstract}

Kata kunci : Pemberdayaan Masyarakat, ketahanan pangan,

\section{Pendahuluan}

Masalah pertanian, khususnya pangan, telah lama mendapat perhatian, Hal ini karena perkembangan penduduk mengikuti deret ukur, sedangkan perkembangan pangan mengikuti deret hitung (Malthus, dalam Rusli, 1989). Desakan untuk memenuhi kebutuhan pangan bagi penduduknya yang terus 
berkembang telah menyadarkan Negara untuk meningkatkan ketahanan pangan nya. Ketahanan Pangan adalah kondisi terpenuhinya kebutuhan Pangan dan Gizi bagi negara sampai perseorangan. Oleh karena itu, maka upaya pemberdayaan petani agar petani dapat meningkatkan agar produksi pangan sehingga dapat mendukung ketahanan pangan.

Pemberdayaan masyarakat, dilakukan melalui kegiatan, menciptakan suasana atau iklim yang memungkinkan potensi masyarakat berkembang (enabling). memperkuat potensi atau daya yang dimiliki oleh masyarakat (empowering). memberdayakan mengandung pula arti melindungi. Pemberdayaan merupakan suatu upaya dengan tetap memperkuat potensi atau daya yang dimiliki oleh setiap masyarakat. Perkuatan ini meliputi langkahlangkah nyata dan menyangkut penyediaan berbagai masukan (input) serta membuka akses kepada berbagai peluang (upportunities) yang nantinya dapat membuat masyarakat menjadi semakin berdaya. Indonesia mempunyai program untuk meningkatkan hasil pertanian unt mendukung ketahanan pangan melaluhi pemberdayaan petani dengan GAPOKTAN (Gabungan kelompok tani). Gapoktan merupakan kumpulan beberapa kelompok tani yang bergabung dan bekerjasama untuk meningkatkan efisiensi usaha (Permentan No. 273 th 2007 tentang Pedoman Pembinaan Petani ). Berdayanya petani dalam meningkatkan produksi pertanian maka akan mendukung program pemerintahan dalam meningkatakan ketahann pangan di Indonesia.

Kabupaten Gresik dikenal sebagai salah satu kawasan industri utama dan penghasilan tertinggi sebesar 49,52\%, bidang pertanian unggul atas produksi beras, jagung tetapi sebagai penghasilan terendah sebesar 8,61\% (Profil KabupatenGresik.com). Desa Menganti adalah sebuah kecamatan di Kabupaten 
Gresik, Provinsi Jawa Timur, Indonesia. Desa Menganti memiliki luas wilayah 784 Ha. Sebagian besar wilayah Desa Menganti merupakan kawasan pemukiman, industri kecil / industri rumah tangga, pertanian dan perdagangan.

Desa Menganti terletak berdekatan dengan kota Surabaya yang memiliki sektor perindustrian sangat banyak sehingga melebar sampai masuk di Menganti yang menyebabkan perindustrian di desa Menganti menjadi lebih banyak di bandingkan dengan pertanian, dengan demikian sektor pertanian di Menganti menjadi berkurang dengan sektor perindustrian. Pemerintah Gresik terutama Kepala Desa Menganti mengkhawatirkan pertanian di Desa Menganti semakin sedikit dikarenakan peralihan lahan,

Gapoktan Menganti merupakan gabungan dari enam Kelompok Tani (Poktan) di Desa Menganti yaitu Poktan Karang Turi, Poktan Krajan, Poktan Dukuhan, Poktan Wonokoyo, Poktan Ploso Kerep, dan Poktan Bibis Kidul. Jumlah seluruh anggota Gapoktan Menganti adalah 510 orang. Banyaknya petani di Kabupaten Gresik yang tidak dapat melakukan proses pertaniannya dikarenakan harga pupuk yang meninggi sehingga ketahanan pangan di Kabupaten Gresik menurun. Dengan adanya permasalahan ini pemerintah memberikan program pemberdayaan teknologi petani melalui Gabungan Kelompok Tani (GAPOKTAN) agar pertanian di Kabupaten Gresik dapat berjalan dan peran Gapoktan membantu petani dan memberdayakan petani agar pertanian dapat berjalan sehingga ketahanan pangan juga dapat meningkat. Penelitian ini mengangkat permasalahan tentang bagaimana pemberdayaan petani melaluhi program yang dilaksanakan oleh Gapoktan di Desa Menganti Kecamatan Menganti Kabupaten Gresik.

\section{Teoritik}


Pemberdayaan menunjuk pada usaha realokasi sumber daya melalui pengubahan struktur sosial. Pemberdayaan adalah suatu cara yang diarahkan kepada masyarakat, organisasi atau komunitas agar mampu menguasai (berkuasa atas) kehidupannya (Rappaport dalam Suharto,1998:3). Tujuan pemberdayaan adalah memperkuat community self-reliance atau kemandirian. berpendapat bahwa tujuan pemberdayaan adalah untuk meningkatkan kekuasaan orang-orang yang lemah atau tidak beruntung. (Ife dalam Edi Suharto,2009:58) Pemberdayaan sebagai proses memiliki lima dimensi yaitu: a). Enabling. b) Empowering, c) Protecting d) Supporting e) Fostering (Edi Suharto dalam Abu Huraerah (2008:89),

Pemberdayaan masyarakat merupakan upaya untuk meningkatkan harkat martabat lapisan masyarakat, yang dalam kondisi sekarang tidak mampu melepaskan dirinya dari perangkap kemiskinan dan keterbelakangan. upaya upaya dalam pemberdayaan masyarakat dapat dilakukan melalui tiga tahap, antara lain : 1) Menciptakan suasana atau iklim tolaknya yang memungkinkan masyarakat untuk berkembang. Disini titik tolaknya bahwa setiap manusia, setiap masyarakat memiliki potensi yang dapat dikembangkan, artinya tidak ada masyarakat yang sama sekali tanpa daya. 2). Memperkuat potensi daya yang dimiliki oleh masyarakat (Empowering). Dalam rangka ini perlu langkah-langkah yang lebih positif, Selain menciptakan iklim dan suasana. Penguatan ini merupakan / meliputi langkah-langkah nyata dan menyangkut penyediaan berbagai masukan, serta pembukaan akses kedalam berbagai peluang yang akan membuat masyarakat menjadi makin berdaya. Dalam rangka pemberdayaan ini upaya yang amat pokok adalah peningkatan taraf pendidikan, derajat kesehatan, serta akses kedalam sumber-sumber kemajuan ekonomi seperti modal, teknologi, 
informasi, lapangan kerja, dan pasar. 3).Pemberdayaan mengandung pula arti melindungi (Protecting ) Dalam proses pemberdayaan harus dicegah yang lemah menjadi bertambah lemah karena kekurangberdayaan dalam menghadapi yang kuat. Oleh karena itu, perlindungan dan pemihakkan kepada yang lemah sangat mendasar sifatnya dalam konsep pemberdayaan masyarakat. (Kartasasmita dalam Mashoed (2004:46). Ketahanan Pangan rumah tangga adalah kemampuan untuk memenuhi pangan anggota keluarga dari waktu ke waktu dan berkelanjutan baik dari produk sendiri atau membeli jumlah, mutu sesuai dengan lingkungan social budaya melakukan kegiatan social secara produksi.

\section{Metode Penelitian}

Penelitian deskriptif kualitatif. bersifat deskriptif, yang mencoba menggambarkan secara mendalam suatu obyek penelitian berdasarkan fakta-fakta yang tampak sebagaimana adanya, dengan menggunakan pendekatan penelitian kualitatif, untuk memperoleh gambaran yang komprehensif dan mendalam. Bogdan dan Taylor dalam Moleong (1975:5). Fokus dalam penelitian ini adalah upaya pemberdayaan ekonomi dan pemberdayaan Teknologi bagi petani sebagai upaya meningkatkan hasil pertanian.

Lokasi penelitian ini di Desa Menganti Kecamatan Menganti Kabupaten Gresik dengan pertimbangan bahwa di Desa Menganti merupakan daerah yang telah melaksanakan program pemberdayaan. Dengan demikian maka penulis tertarik untuk meneliti Pemberdayaan Petani melalui program GAPOKTAN.

Teknik analisa data yang digunakan dalam penelitian ini adalah analisa dengan menggunakan model interaktif (interactive models of analysis) yang dikembangkan oleh Miles dan Huberman (1992:16). Seperti dalam skema berikut 


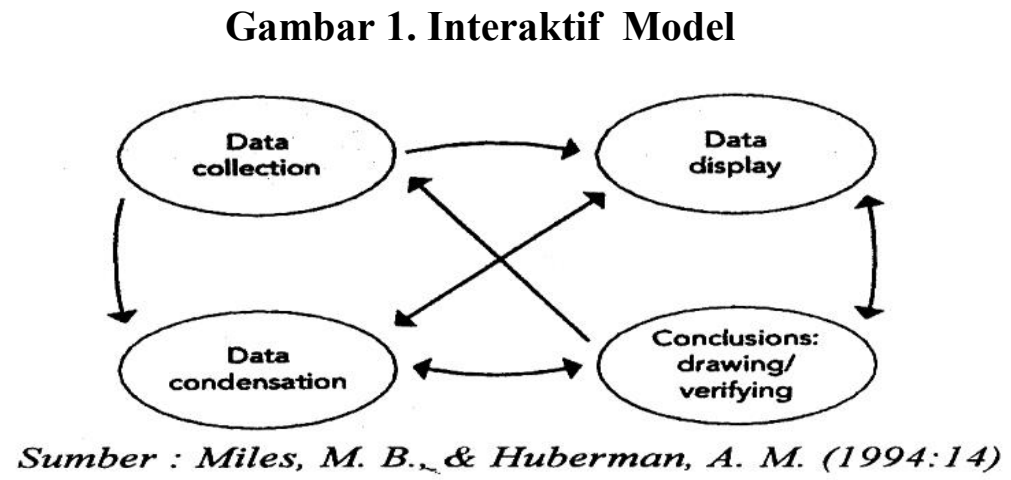

Setiap penelitian memerlukan standar untuk melihat derajat kepercayaannya atau kebenarannya dari hasil penelitiannya. Dalam penelitian kualitatif, standar tersebut disebut dengan keabsahan data. Menurut Lincoln dan Guba (dalam Moleong, 2004:324). Untuk menetapkan keabsahan data maka diperlukan teknik pemeriksaan. Pelaksanaan teknik pemeriksaan didasarkan atas empat kriteria yang digunakan yaitu : Derajat Kepercayaan (Credibility), Keteralihan (Transferability), Keteguhan (Dependability), Kepastian (Conformability).

\section{Hasil Dan Pembahasan}

Desa Menganti memiliki luas wilayah $784 \mathrm{Ha}$. Rincian penggunaan lahan diuraikan pada tabel di bawah ini:

Tabel 1. Luas Wilayah menurut Penggunaan

\begin{tabular}{|c|l|r|}
\hline No & \multicolumn{1}{|c|}{ Penggunaan } & Luas Lahan (Ha) \\
\hline 1 & Tanah Sawah & $240,8 \mathrm{Ha}$ \\
\hline 2 & Tanah Tegalan & $132 \mathrm{Ha}$ \\
\hline 3 & Perkarangan & $381,58 \mathrm{Ha}$ \\
\hline 4 & Waduk & $13 \mathrm{Ha}$ \\
\hline 5 & Makam & $7,52 \mathrm{Ha}$ \\
\hline 6 & Lapangan & $2 \mathrm{Ha}$ \\
\hline 7 & Jalan & $8,7 \mathrm{Ha}$ \\
\hline
\end{tabular}

Sumber : Kantor Desa Menganti, April 2015 
Jumlah penduduk berdasarkan mata pencaharian, penduduk Desa Menganti memiliki keanekaragaman mata pencaharian yang akan disajikan pada tabel di bawah ini :

Tabel 2. Jumlah Penduduk berdasarkan Mata Pencaharian

\begin{tabular}{|c|l|c|c|}
\hline No & Jenis Mata Pencaharian & Jumlah (Orang) & Prosentase (\%) \\
\hline 1 & Petani / Buruh Tani & 1761 & 22,75 \\
\hline 2 & Peternakan & 3 & 0,04 \\
\hline 3 & Nelayan / Perikanan & 18 & 0,23 \\
\hline 4 & TNI/Polri & 25 & 0,32 \\
\hline 5 & Pegawai Negeri Sipil & 51 & 0,66 \\
\hline 6 & Pegawai Swasta & 1446 & 18,68 \\
\hline 7 & Wirausaha / Pedagang & 1600 & 20,67 \\
\hline 8 & Belum Bekerja & 2835 & 36,63 \\
\hline \multicolumn{2}{r}{ Jumlah } & $\mathbf{7 7 3 9}$ & $\mathbf{1 0 0}$ \\
\hline
\end{tabular}

Sumber : Kantor Desa Menganti, April 2015

Dari tabel di atas dapat diketahui mayoritas penduduk Desa Menganti adalah sebagai petani / buruh tani dengan prosentase $22,75 \%$. Hal ini membuktikan bahwa pertanian masih menjadi mata pencaharian terpenting didesa tersebut dan masih perlu peningkatan pemberdayaan petani agar dapat meningkatkan hasil pertanian dan mendukung ketahanan pangan. Gabungan Kelompok Tani (Gapoktan) Desa Menganti dibentuk untuk meningkatkan kesejahteraaan masyarakat Desa yang berdaya guna dan berhasil guna serta untuk meningkatkan hasil produksi pertanian. Gapoktan Desa Menganti telah berdiri pada tahun 2005. tahun 2012 terjadi pergantian pengurus Gapoktan Desa Menganti berdasarkan Surat Keputusan Ketua Desa Nomor 06 Tahun 2012 tentang Pembentukan Pengurus Gabungan Kelompok Tani (Gapoktan) Menganti.

Gapoktan Menganti merupakan gabungan dari enam Kelompok Tani (Poktan) di Desa Menganti berikut di bawah ini adalah jumlah anggota gapoktan berdasarkan kelompok tani:

Tabel 3. Jumlah Anggota Gapoktan Menganti berdasarkan Kelompok Tani 


\begin{tabular}{|c|l|c|c|}
\hline No & \multicolumn{1}{|c|}{ Nama Poktan } & Jumlah (Orang) & Prosentase (\%) \\
\hline 1 & Poktan Karang Turi & 110 & 21,57 \\
\hline 2 & Poktan Krajan & 76 & 14,90 \\
\hline 3 & Poktan Dukuhan & 75 & 14,71 \\
\hline 4 & Poktan Wonokoyo & 110 & 21,57 \\
\hline 5 & Poktan Ploso Kerep & 64 & 12,54 \\
\hline 6 & Poktan Bibis Kidul & 75 & 14,71 \\
\hline \multicolumn{2}{|c|}{ Jumlah } & $\mathbf{5 1 0}$ & $\mathbf{1 0 0}$ \\
\hline
\end{tabular}

Sumber: Gapoktan Menganti, April 2015

\section{Pemberdayaan Ekonomi}

Pemberdayaan Ekonomi adalah upaya memberikan daya kepada petani dalam bidang pertanian dengan dilakukan dengan memberikan subsidi Pupuk dan bibit tanam dan Permodalan. Distribusi pupuk subsidi untuk seluruh anggota Gapoktan , Gapoktan menerima per tahun per musim panen sebesar 50 - 52 Ton yaitu 50 ton Pupuk Urea, 50 ton pupuk Ponska, dan 25 ton Pupuk Organik per musim tanam. Bantuan Bibit tanam, biasanya hanya 50 Ton 2 kali diberikan rutin tetapi pemerintah memberikan tidak secara konsekwensi kadang berkurang jumlahnya khusus pupuk subsidi, tetapi bibit tanam tidak rutin diberikan oleh pemerintah.

Pelaksanaan program pendistribusian subsidi pupuk dan bibit tanam, menunjukkan bahwa upaya tersebut sangatlah bermanfaat bagi anggota Gapoktan. Program tersebut dianggap dapat membantu dalam pengembangan usaha tani dan melancarkan proses pertanian. Kegiatan pendistribusian pupuk bersubsidi dan bibit tanam dilaksanakan, tempat pelaksanaannya yaitu di Kantor Balai desa yng dilaksanakan oleh Sekretariat Gapoktan. Penerima bantuan pupuk bersubsidi dan bibit tanam adalah semua anggota Gapoktan. Pendistribusian pupuk bersubsidi, tidak sesuai dengan jatah yang seharusnya diberikan untuk setiap musim tanam seharusnya 100 Ton tetapi kenyataannya hanya mendapat 50 Ton. Progran bantuan bibit tanam diberikan pada waktu setelah musim tanam kepada Anggota 
Gapoktan, seharusnya sebelum musim tanam. Sehingga dianggap kurang mempunyai dampak bagi peningkatan hasil pertanian.

Permodalan, diberikan dengan sistem Simpan pinjam yang dibuka pada saat awal berdirinya Gapoktan pada tahun 2005. Sistem pinjamannya secara bergulir setiap 1 bulannya 100 orang, 1 gulirnya maksimal Rp1.000.000,- , pinjaman dana tersebut dari dana hibah atau PUAP. Syarat dari simpan pinjam yaitu harus menjadi anggota Gapoktan, berdomisili wilayah Gapoktan Menganti.

Program pemberian Modal syaratnya harus mengurus surat keterangan tidak mampu dari desa. Jumlah Modalnya 100 juta ditambah iuran anggota per anggota Rp.10.000/bulan. Pengembalian simpan pinjam pada waktu selesai musim Panen. Bantuan modal hanya diberikan kepada para petani yang tidak mampu sebagai upaya untuk memberikan daya dalam upaya meningkatkan hasil pertanian.

Menurut Suharto (1987) dalam Huraerah (2008:89), pemberdayaan sebagai proses memiliki lima dimensi yaitu :Enabling, Empowering, Protecting, Supporting, Fostering. Pemberdayaan Ekonomi melalui pendistribusian pupuk bersubsidi dan bibit tanam serta simpan pinjam dan permodalan sesuai dengan yang disampaikan oleh Suharto (1987) dalam Huraerah (2008:89) yakni : Pertama Enabling adalah menciptakan suasana atau iklim yang memungkinkan potensi masyarakat berkembang secara optimal. Pemberdayaan harus mampu membebaskan masyarakat dari sekat-sekat struktural dan kultural yang menghambat. Dalam hal ini dengan adanya kegiatan pendistribusian pupuk bersubsidi dan bibit tanam dapat memudahkan Anggota Gapoktan dalam mengembangkan usaha pertaniannya secara optimal, sehingga dapat menigkatkan hasil pertanian yang diharapkan dapat memberikan dampak pada penguatnya ketahanan pangan didesa tersebut. Tetapi pemerintah memberikan jatah pupuk 
bersubsidi tidak sesuai dengan jatah yang ditentukan. Begitu juga dalam kegiatan pemberian bibit tanam kepada Gapoktan pemerintah tidak memeberikan pada saat sebelum musim tanam.

Kedua, fostering yaitu $\mathrm{m}$ emelihara kondisi kondusif agar tetap terjadi keseimbangan distribusi kekuasaan antara berbagai kelompok masyarakat. Pemberdayaan harus mampu menjamin keseimbangan dan keselarasan yang memungkinkan setiap orang memperoleh kesempatan usaha. Dalam hal ini Pemberdayaan Ekonomi melalui simpan pinjam dan pemberian modal mampu menjamin keseimbangan dan keselarasan yang memungkinkan setiap anggota Gapoktan memperoleh kesempatan usaha.

Ketiga, Protecting yaitu melindungi masyarakat terutama kelompokkelompok lemah agar tidak tertindas oleh kelompok-kelompok kuat dan dominan, menghindari persaingan yang tidak seimbang, mencegah terjadinya eksploitasi kelompok kuat terhadap yang lemah. Pemberdayaan harus diarahkan pada penghapusan segala jenis diskriminasi dan dominasi yang tidak menguntungkan masyarakat kecil. Pemberdayaan harus melindungi kelompok lemah, minoritas dan masyarakat terasing. Pemberdayaan ekonomi melalui pendistribusisan subsidi pupuk dan bibit tanam melindungi kelompok tani agar tidak mempunyai ketergantungan pada sistem ijon atau tengkulak dan renternir dalam melakukan usaha pertaniannya. Pemberdayaan ekonomi melalui simpan pinjam dan permodalan bertujuan untuk memberdayakan secara ekonomi masyarakat petani sehingga terhindar dari pinjaman renternir.

Pemberdayaan Ekonomi yang telah dilakukan dengan proses enabling dan fostering, protecting, sehingga Pemberdayaan ekonomi melalui kegiatan pendistribusian pupuk bersubsidi dan bibit tanam sudah dilakukan secara 
rutin tetapi belum maksimal. Hal ini dikarenakan dalam pendistribusian pupuk bersubsidi pemerintah memberikan jatah pupuk tidak sesuai dengan jatah yang seharusnya. Begitu juga dalam kegiatan pemberian bibit tanam kepada Gapoktan pemerintah tidak memberikan pada saat sebelum musim tanam. Dari Aspek ketahanan pangan maka pemberdayaan ini diharapkan dapat memberikan dampak dalam pemenuhi kebutuhan pangan dan gizi bagi keluarga,

\section{Pemberdayaan Teknologi}

Pemberdayaan Teknologi dilakukan dengan kegiatan Sekolah Lapang yang bertujuan untuk meningkatkan ketrampilan dalam bertani dengan mengembangkan pengetahuan petani dalam cara tanam, pemupukan, dan lainnya. Sekolah Lapang diharapkan untuk mendorong meningkatnya hasil pertanianm sehingga memberikan dampak pada petani lebih bisa berdaya terutama tidak buta dalam hal teknologi pertanian terbaru atau modern. Peserta mengikuti sekolah lapang yaitu seluruh anggota Gapoktan dan yang paling utama adalah lahan pertaniannya yang dibuatkan LL (Laboratorium Lapangan) besarnya 1 hektar. Jumlah yang mengikuti Sekolah Lapang yaitu seluruh anggota Gapoktan Desa Menganti setiap musim panen sekitar 40 sampai 60 orang karena di batasi SLPTT lahanya maksimal 25 Hektar. Adapun pengenalan kegiatan Sekolah Lapang kepada anggota Gapoktan yaitu yang pertama memberikan undangan kepada anggota Gapoktan untuk tempat dan waktu berkumpulnya baik berkumpul di sawah, rumah anggota gapoktan atau Balai desa, tergantung yang paling enak dimana.

Sekolah Lapang tidak selalu dilakukan di tempat tempat resmi biasanya kebanyakan di sawah dan langsung praktek. Pelaksanaan Sekolah Lapang pada waktu sebelum musim tanam sebanyak 8x dengan pembagian bibit 
tanam dan pupuk terus pertemuan sekolah lapang sendiri sebanyak 6x dan pemetakan hasil panen selama 1x. Pemetakan sebesar $2 \frac{1}{2} \mathrm{~m}$ x $2 \frac{1}{2} \mathrm{~m}$ sebagai lahan unyuk praktek sekolah lapang. Manfaat adanya Kegiatan Sekolah Lapang bagi anggota Gapoktan yaitu anggota Gapoktan mendapatkan ilmu pertanian, cara - cara bertanam secara modern, pengobatan, pemupukan, teknologi pertanian yang baru dan bermanfaat bagi usaha pertaniannya, dan mengetahui paska panen Penyuluhan dilaksanakan bagi anggota Gapoktan Desa Menganti yaitu bertambahnya ilmu pertanian bagi anggota Gapoktan, manfaat yang diharapkan adalah merubah image para petani yang sulit menerima perubahan dalam teknik bertani, petani bisa lebih berdaya, dan bisa meningkatkan hasil pertanian. Kegiatan penyuluhan yang diberikan yaitu yang pertama tentang pengenalan bibit - bibit tanam, pengenalan pupuk, pengenalan obat - obatan dan pengenalan teknologi pertanian terbaru atau yang modern. Setelah itu baru cara tanam, cara memilih bibit sesuai lahan, cara pemupukannya yang benar. Penyuluhan diberikan oleh para penyuluh pertanian dan ketua Gapoktan. Penyuluhan dilakukan secara rutin 1 bulan 1 kali , kadang - kadang sewaktu waktu kalau petani membutuhkan penyuluhan seperti tanya - tanya , dan kalau ada masalah tentang pertaniannya semisal ada penyerangan hama, panjang leher batang jagung berpenyakitan kemudian kita menyelidiki dan lain - lain. Berikut adalah gambar penyuluhan kepada anggota Gapoktann.

Pemberdayaan teknologi dalam Sekolah Lapang bertujuan untuk meningkatkan hasil panen para petani. Petani dapat mengembangkan cara tanam, pemupukan, dan lainnya. Peserta sekolah lapang yaitu seluruh anggota GapoktanDesa Menganti setiap musim panen sekitar 40 sampai 60 orang karena 
di batasi SLPTT lahanya maksimal 25 Hektar, dengan menggunakan lahan pertanian untuk LL (Laboratorium Lapangan) besarnya 1 hektar.

Pemberdayaan teknologi dalam penyuluhan yang diberikan yaitu yang pertama tentang pengenalan bibit - bibit tanam , pengenalan pupuk, pengenalan obat - obatan dan pengenalan teknologi pertanian terbaru atau yang modern. Setelah itu baru cara tanam, cara memilih bibit sesuai lahan, cara pemupukannya. Menurut Suharto (1987) dalam Huraerah (2008:89), pemberdayaan sebagai proses memiliki lima dimensi yaitu : a) Enabling, b) Empowering, c) Protecting. d) Supporting, e) Fostering. Pemberdayaan teknologi melalui Sekolah lapang dan penyuluhan sesuai dengan yang disampaikan oleh Suharto (1987) dalam Huraerah (2008:89), yakni , Pertama, Empowering adalah penguatan pengetahuan dan kemampuan yang dimiliki masyarakat dalam memecahkan masalah dan memenuhi kebutuhan-kebutuhannya. Pemberdayaan harus mampu menumbuh kembangkan segenap kemampuan dan kepercayaan diri masyarakat yang menunjang kemandirian.Dalam hal ini penguatan pengetahuan dan kemampuan yang dimiliki oleh anggota Gapoktan dalam memecahkan masalah dilakukan melaui kegiatan Sekolah lapang dan Penyuluhan.

Kedua, supporting yaitu pemberian bimbingan dan dukungan kepada masyarakat lemah agar mampu menjalankan peran dan fungsi kehidupannya. Pemberdayaan harus mampu menyokong masyarakat agar tidak terjatuh ke dalam keadaan dan posisi yang semakin lemah dan terpinggirkan. Dalam hal ini dengan adanya sekolah lapang dan penyuluhan mampu memberikan bimbingan dan dukungan kepada anggota Gapoktan sehingga mampu menjalankan peran dan fungsi dalam usaha pertaniannya. 
Pemberdayaan Teknologi telah dilakukan melaluhi proses empowering dan supporting dengan kegiatan sekolah lapang dan penyuluhan sudah dilakukan secara rutin telah memberikan dampak bagi peningkatan pengetahuan tentang teknologi pertanian sehingga dapat meningkatkan ketrampilan petani.

Menurut Suharto (2009:66) Dalam konteks pekerjaan sosial, pemberdayaan dapat dilakukan melalui tiga arus atau matra pemberdayaan (empowerment setting): mikro, mezzo dan makro. Berdasarkan temuan di lapangan Pemberdayaan petani melalui Gapoktan, pemberdayaan petani melalui Gapoktan dilakukan melalui pemberdayaaan Mezzo dimana pemberdayaan dilakukan terhadap anggota Gapoktan dengan menggunakan pendekatan kelompok sebagai media intervensi. Sekolah lapang dan penyuluhan digunakan sebagai strategi dalam meningkatkan kesadaran, pengetahuan, dan ketrampilan agar anggota Gapoktan memiliki kemampuan dalam memecahkan permasalahan pertanian yang dihadapi.

Kebijaksanaan pemberdayaan masyarakat secara umum dapat dipilah dalam tiga kelompok yaitu: 1)'Kebijaksanaan yang secara tidak langsung mengarah pada sasaran tetapi memberikan dasar tercapainya suasana yang mendukung kegiatan sosial ekonomi masyarakat. 2) 'Kebijaksanaan yang secara langsung mengarah pada peningkatan kegiatan ekonomi kelompok sasaran. 3) 'Kebijaksanaan khusus yang menjangkau masyarakat miskin melalui upaya khusus.

Pemberdayaan petani melalui Gapoktan sesuai dengan kebijaksanaan pemberdayaan yaitu kebijaksanaan khusus yang menjangkau masyarakat miskin melalui upaya khusus. Dalam hal ini Pemberdayaan petani melalui Gapoktan merupakan kebijaksanaan khusus yang menjangkau masyarakat 
petani, khususnya masyarakat petani yang miskin. Dalam mendukung ketahanan pangan adalah dengan meningkatnya keberdayaan petani dalam teknologi pertanian memeberikan ketrampilan dalam bertani sehingga ekan meningkatkan produksi pertanian yang akan berarti meningkannya keberdayan keluarga dalam memenuhi kebutuhan pangananya.

\section{Kesimpulan}

Pemberdayaan Ekonomi melalui Pendistribusian subsidi pupuk dan Bibit tanam menunjukan bahwa sudah terlaksana tetapi masih belum optimal, karena pembagian subsidi pupuk dan bibit tanam tidak sesuai dengan ketentuan. Upaya ini dapat memberikan peningkatan kekuatan bagi petani anggota Gapoktan dalam usaha produksi pertanian. Namun Pemerintah perlu lebih memperhatikan pendistribusian pupuk dan bibit tanam agar dalam pembagian itu dilakukan sebelum musim tanam kepada Anggota Gapoktan.

Program pemberian modal telah dilakukan dengan dampak yang cukup nyata membantu petani dalam melakukan usaha pertanian, namun perlu adanya pemahaman kepada anggota Gapoktan bahwa dana simpan pinjam dan permodalan hanya digunakan unutuk kebutuhan produktif dan memenuhi kebutuhan usaha pertanian.

Pemberdayaan Teknologi melalui Sekolah Lapang dan penyuluhan

di Desa Menganti sudah dilaksanakan secara rutin dengan memberikan pengetahuan tentang teknologi pertanian. Hal ini memberikan peningkatan, kemampuan teknologi bagi para petani anggota Gapoktan dalam usaha pertanian. Pemberdayaan petani melalui program Gapoktan di Desa Menganti sudah berjalan 
dengan baik dan memberikan hasil dalam peningkatan keberdayaan anggota Gapoktan dalam mengembangkan usaha pertanian yang dimiliki.

$$
\text { Dengan adanya program pemberdayaan tersebut dirasakan }
$$

memang ada dampak positif bagi meningkatnya hasil pertanian dan dengan meningkatnya hasil pertanian tersebut diharapkan memberikan kontribusi dalam meningkatkan ketahanan pagan di Kabupaten Gresik,

\section{DAFTAR PUSTAKA}

Chang, William. 2014. Metodelogi Penelitian Ilmiah. Jakarta: Erlangga .

Harry, Hikmat. 2010. Strategi Pemberdayaan Masyarakat. Bandung : Humaniora Utama Press.

Hasan, Iqbal. 2004. Analisis data Penelitian Dengan Statistik. Jakarta: Bumi Aksara.

Huraerah, Abu. 2008. Pengorganisasian dan Pengembangan Masyarakat, Model dan Strategi Pembangunan. Bandung : Humaniora Utama Press.

Miles, Mathew\&Huberman, Michael dan Rohidi, Tjejep\&Mulyarto. 2014. Analisis Data Kualitatif. Jakarta : Universitas Indonesia (UI - Press)

Miles, Mathew\&Huberman, Michael. 1994. Qualitative Data Analysis. Singapore : Arizona State University/

Moleong, Lexy. 2006. Metodelogi Penelitian Kualitatif. Bandung: Rosdakarya.

Rohendi, Tjetjep. 1992. Analisis Data Kualitatif. Jakarta : Universitas Indonesia.

Suharto, Edi. 2009. Membangun Masyarakat Memberdayakan Rakyat. Bandung: Refika Aditama.

Wrihatnolo, Randy R. 2007 Manajemen Pemberdayaa. Jakarta: Riant Nugroho Dwidjowijoto. 